\title{
Towards a More Just Canadian Education- migration System: International Student Mobility in Crisis
}

\author{
LISA RUTH BRUNNER \\ University of British Columbia, Canada
}

\begin{abstract}
Education-migration, or the multi-step recruitment and retention of international students as immigrants, is an increasingly important component of both higher education and so-called highly-skilled migration. This is particularly true in Canada, a country portrayed as a model for highly-skilled migration and supportive of international student mobility. However, education-migration remains underanalyzed from a social justice perspective. Using a mobility justice framework, this paper considers COVID-19's impact on Canada's education-migration system at four scales: individuals, education institutions, state immigration regimes, and planetary geoecologies. It identifies ethical tensions inherent to Canada's education-migration from a systems-level and suggests that a multi-scalar approach to social justice can both usefully complexify discussions and introduce unsettling paradoxes. It also stresses that the COVID-19 pandemic offers an opportunity to reimagine rather than return.
\end{abstract}

KEYWORDS internationalization; international students; higher education; mobility justice; skilled migration; international student mobility

When announcing Canada's 2021-2023 Immigration Levels Plan, Immigration, Refugees and Citizenship Canada (IRCC) Minister Marco Mendicino described parts of Canada as "starved for people" (CPAC, 2020, 21:53). Referring to immigrants as something for a state to consume was both disturbing (in its dehumanization) and fitting (in its extension of Canada's capitalist settler-colonial project) (Chatterjee, 2019). For a country in which immigration policy is population policy (Ley \& Hiebert, 2001), the COVID19 pandemic's reduction of international human mobility had major repercussions. In just one year, Canada's population growth swung from a record high to a record low (StatsCan, 2020f). Economic recovery, the government signaled, depended on immigration recovery (IRCC, 2020a). 
But to claim Canada hungered for people was not precise enough. It was Canada's "domestic immigration pool" that would be a focus, Mendicino went on, highlighting international students as "a very attractive pool... to look very closely at" (Hagan \& Bolongaro, 2020, para. 12). He offered a "simple" message for international students: "we don't just want you to study here, we want you to stay here" (IRCC, 2021a, para. 6).

Viewing international students as an immigrant source is just one element of what has become a distinct education-migration, or "edugration," filtering system: those who (1) gain admission to, and graduate from, a Canadian higher education (HE) institution may (2) compete in the Canadian labour market for a limited time, during which those who gain sufficient work experience may (3) remain in Canada permanently (Brunner, in press). In contrast to the United Nations' (2006) supposed triple win - where migration simultaneously benefits migrants, countries of origin, and destination countries - education-migration is painted as a different triple win: (1) students gain a valuable education and desirable citizenship; (2) HE gains revenue, labour, and diversity; and (3) Canada gains human capital, tax revenue, population growth, and soft power. Like much in immigration and HE today, individual and nationalist economic utility are the system's driving forces (McCartney, 2020).

This problematic framing ignores the system's larger replications of privilege and power, invisiblizing externalized losses (such as brain drain) and problematic enablements (such as the dominance of a hierarchical global imaginary rooted in Western supremacy which dictates the desirability of Canadian education) (Stein \& Andreotti, 2016). In any large-scale disruption, patterns of privilege and power persist, "but the narratives that justify them seem increasingly implausible" (Apostolidis \& McBride, 2020, p. S-82). Some see recent disruptions such as COVID-19 and the climate crisis as opportunities to finally reimagine a more sustainable, reciprocal model of both international education (El Masri \& Sabzalieva, 2020; Stein, 2019b; Yang, 2020) and international migration (Bender \& Arrocha, 2017; Sharma, 2020).

In considering the ethics of Canada's education-migration system at this critical junction, this paper makes two contributions. First, it details Canadian education-migration policies before, during, and potentially after the COVID19 pandemic. Second, taking a mobility justice approach, it explores their implications at multiple scales. Constrained by the space of a single paper, the latter offers merely a taste of deeper conversations to be had. However, in attending to overlapping systemic vulnerabilities, it recognizes that mobility injustices occur not only after a migrant enters a country, but are, in fact, "the process through which unequal spatial conditions and differential subjects are made" (Sheller, 2019, p. 26). In an effort to more fully grapple with the system's complexities, it includes, yet also goes beyond, injustices faced by international students themselves. 
I begin by summarizing mobility justice and showing how its multi-scalar faming helps situate education-migration's ethical issues. I then describe Canada's education-migration system specifically and contribute to its needed contextualization (Riaño et al., 2018) by providing a pre-COVID-19 snapshot, followed by an outline of key COVID-19 policy responses. I outline examples of ethical issues revealed at each scale and conclude by discussing why this approach might complexify our collective inquiry around the ethics of education-migration in today's uncertain times.

\section{Mobility Justice}

Mobility justice was only recently developed as a framework (e.g., Sheller, $2011,2018,2019)$ and is used in disparate ways (Cook \& Butz, 2019). The term emerged from the mobilities paradigm, which critiqued the moral and ideological privileging of "sedentarist" perspectives - i.e., those which uphold prevailing "understandings of 'society', 'social structures', 'citizenship' and 'governance' in which static social relations are ostensibly produced, governed and bounded by the nation-state" (Cook \& Butz, 2019, p. 10; Sheller \& Urry, 2006; Urry, 2007). Instead, mobility was seen as foundational to social relations, necessitating a focus on how power is organized (at various scales) around the governance of mobility (in various forms) - not just movement but also immobility, stillness, and stuckness (Cresswell, 2011, 2012). Because modernity has increased and restricted mobility in uneven ways, concepts such as the kinetic elite/underclass (Cresswell, 2006) and the potential capacity of mobility (described as motility) help us understand mobility capital (Kaufmann et al., 2004) as both an outcome of, and mechanism of reproducing, systemic inequalities (Benz, 2019).

Mobility justice builds on this paradigm with a mobility-focused take on social justice theory. Following contemporary activist movements, it seeks a common framework to link social justice struggles (Sheller, 2019). Such struggles range from embodied, micro-level differential (im)mobilities (e.g., racialized and gendered spatial relations) to macro-level patterns of global (im)mobilities (e.g., decolonialism and climate justice). This is a tall order, requiring a practice which itself is mobile as it jumps across scales and ways of thinking about justice; indeed, its quest for "one common framework" (Sheller, 2019, p. 33) risks grand theorizing. However, in compliment to more fine-grained analyses, it offers a systems-levels approach while also showing how justice itself "is a process of emergent relationships" based on the "interplay of diverse (im)mobilities" (Sheller, 2018, p. 20).

A key feature of mobility justice is its intersectional, multi-scalar approach. Scale's full theoretical history is beyond the scope of this paper; briefly, as a socially-constructed concept (Marston, 2000), scale does risk oversimplification, overgeneralization, arbitrary delineation, and legitimizing 
the exclusion of actors and ideas (Glick Schiller \& Çaglar, 2011; van Lieshout et al., 2011). The conventional reliance on micro, meso, and macro levels also has limitations. However, scales are ideally not used as "fixed nested sociospatial units of territory or governance," but rather dynamic and relative "repositionings of territorially based forms of organization" operating in the context of global power hierarchies (Glick Schiller \& Çaglar, 2011, p. 72). The intention is not to separate scales (e.g., the local from the global), but to highlight their mutual constitution (Glick Schiller \& Çaglar, 2011) and allow for examinations of uneven applications of power (Lan, 2015).

Multi-scalar analysis of international mobility grew in the past 20 years as researchers acknowledged the limitations of macro-level, quantitative, and methodologically-nationalistic approaches (Xiang, 2013; Glick Schiller, 2015; Williamson, 2015). A specifically intersectional multi-scalar lens of mobility (e.g., Tungohan, 2020) highlights the simultaneous interactions of multiple vectors of differentiation (e.g., gender, race, and class) across scales (Mahler et al., 2015). Because exclusionary and inclusionary structures vary from state to state, people may, for example, "be relatively privileged - and actively seek privilege - in one country to balance the marginalisation in another" (Purkayastha, 2010, p. 40). Intersectional multi-scalar approaches tease out the implications of these concurrent, interlocking systems of power.

While mobility justice is just one possible approach for analyzing education-migration, it is useful for two reasons. First, it helps rescale questions of ethics when analyzing (im)migration policies and laws. Mobilities-focused approaches have already helped focus on "the movement involved in migration, rather than privileging the sending and receiving localities and their perspectives" (King \& Raghuram, 2013, p. 129). However, (im)migration policy and law are still typically viewed "as a relatively insulated and domestic-centered arena" (Shachar, 2006, p. 153). States are undoubtedly key players in governing international student mobility regimes (Brooks \& Waters, 2011), but their policies and laws do not govern only those within their borders. Positing that society as a fixed territory bound by the nation-state no longer exists (Urry, 2000), mobility justice pushes social justice theory "into the "post-societal' present" - a necessary move for it to "remain theoretically, empirically and politically relevant" (Cook \& Butz, 2019, p. 9).

Second, issues of highly uneven (im)mobility came to light at every scale of the COVID-19 pandemic, from cellular virus transmission to global vaccine distribution. The pandemic reinforced existing disparities in who is denied or required to physically work (e.g., Dobusch \& Kreissl, 2020) and who or what is permitted to travel (Sheller, 2020b), with lockdowns and border restrictions applied strategically and unevenly (Sheller, 2020a). It also brought major changes through mass demobilizations (e.g., workplaces, schools, airplanes) and new or renewed mobilizations (e.g., repatriations, telemedicine, online learning) (Sheller, 2020a). Mobility justice's approach is 
well-suited to draw out the significance of COVID-19's impact on migration systems.

In this paper I loosely adopt Sheller's (2018) use of four scales: individuals, education institutions, state immigration regimes, and planetary geoecologies. I offer this organizational rubric as just one initial, partial effort, remembering that scales are "always entangled, intersectional, performative, and constantly being remade" (Sheller, 2018, p. 44). Different or additional scales other than the four proposed could be useful for future work (e.g. the land). What I seek to highlight here is (1) the need to identify the scale at which a social justice claim is made (to interrogate its inevitable limitations), and (2) that by viewing multiple scales together - as multi-scalar approaches, such as mobility justice, urge us to do - their collective contradictions become clearer. This process can both interrupt the desire for universality and enable a layered way of holding paradoxes in view, making "what is invisible noticeably absent" (Ahenakew, 2016, p. 333).

In the next section, I offer a review of the education-migration literature structured by these four scales, to situate this paper, before turning to the Canadian context specifically.

\section{The Ethics of Education-migration}

Education-migration is an example of the talent for citizenship exchange spurred by the global race for so-called highly-skilled, or high-wage, migrants. In this exchange, knowledge and work are exchanged for the acquisition of citizenship in "a stable, democratic, affluent polity" (Shachar, 2006, pp. 158-159; Geddie, 2014). In this way, international student mobility has become a form of social mobility (Kim \& Kwak, 2019; MaldonadoMaldonado, 2014) and commodity, influencing not only individual HE enrolment decisions but HE's structure itself (Baas, 2019). HE institutions and immigrant-dependent countries alike now function as recruiters (rather than gatekeepers) (Shachar, 2006) facilitated by a global education-migration industry (Beech, 2018). As a result, education-migration encompasses several areas, including international student/education mobility, the internationalization of $\mathrm{HE}$, temporary foreign worker mobility, migrant "integration," settler-colonialism, and the global knowledge economy. This involves a complex array of entangled ethical issues.

Imagining a just education-migration system is additionally challenging due to its basis on two meritocratic forms of institutionalized discrimination. Just as Baglay (2017) asked, "can immigration law, whose key function is to screen, differentiate, select, and exclude, meaningfully incorporate social justice values?" (p. 210), we may ask a similar question of HE (Stein, 2019a). Selective HE institutions are by definition exclusionary, and the global expansion of $\mathrm{HE}$ perpetuates, if not exacerbates, societal stratifications (Marginson, 2016). HE may contribute to a common good, but as an 
increasingly globalized commodified good (Locatelli, 2019), its admissions process bears some conceptual resemblance to immigrant selection (Brunner, 2017).

Despite "requir[ing] serious reflection" (Geddie, 2014, p. 245; Kim \& Kwak, 2019), considerations of education-migration's unique, systems-level ethical implications remain limited. Scattered across multiple disciplines, most relevant critiques focus on only one step in the process (e.g., the study period) and one scale (e.g., that of international students). Table 1 maps some key critiques of education-migration (at any step) made with academic Anglophone Global North literature.

\begin{tabular}{|c|c|}
\hline Scale & Social justice issues \\
\hline Individuals & $\begin{array}{l}\text { - Racism, Othering, violence, and exclusion } \\
\text { - Conflicting desirability discourses } \\
\text { - Deficit and lack of agency discourses } \\
\text { - Differential tuition } \\
\text { - Inadequate support services } \\
\text { - Legal temporality and limited rights } \\
\text { - Difficulty obtaining and maintaining (im)migration } \\
\text { status (both temporary and permanent) }\end{array}$ \\
\hline $\begin{array}{l}\text { Educational } \\
\text { institutions }\end{array}$ & $\begin{array}{l}\text { - Academic/linguistic imperialism } \\
\text { - Neoliberalism } \\
\text { - Fragmented educational quality } \\
\text { - Institutions as immigration actors }\end{array}$ \\
\hline $\begin{array}{l}\text { State immigration } \\
\text { regimes }\end{array}$ & $\begin{array}{l}\text { - (Settler) colonialism, in relation to (im)migration } \\
\text { - Meritocratic nationalism } \\
\text { - Brain waste/overeducation }\end{array}$ \\
\hline $\begin{array}{l}\text { Planetary } \\
\text { geoecologies }\end{array}$ & $\begin{array}{l}\text { - Brain drain/abuse and inequitable flows between } \\
\text { Global North and Global South } \\
\text { - Global meritocracy and academic mobility as } \\
\text { reproduction of privilege } \\
\text { - Unsustainability }\end{array}$ \\
\hline
\end{tabular}

Table 1. Social justice issues related to education-migration, by scale.

The scale of individuals is the predominant scale within educationmigration research. This literature focuses on experiences of international students (and in some cases, recent graduates working as temporary foreign 
workers, referred to as TFWs). ${ }^{1}$ Their legal status and relative voluntariness of movement generally affords them a relatively privileged position compared to, say, undocumented workers or asylum seekers (Walia, 2013), although such categories occasionally overlap. Still, this scale highlights uneven and conditional inclusion, both material and at the level of discourse. Justice is generally positioned as being for individuals (i.e., international students, through inclusion in more robust institutions and state supports, or more facilitative immigration policies).

The scales of educational institutions and state immigration regimes have commonalities; the literature positions them as both (1) sites of control and governance, while also (2) vulnerable in their systemic external dependency (e.g., on population/enrolment growth, capital, and labour). In the case of HE institutions, justice is often positioned as being for the public (i.e., those who benefit from education as public good), although the public is defined in different ways (e.g., sometimes bound by a state, sometimes globally). In the case of state immigration regimes, justice is sometimes positioned as being for citizens (or permanent residents) bound within the state; in other cases (such as those found in critiques of state role in settler-colonialism), justice is for Indigenous peoples and nations. Proposed responses at both scales include more robust (or more fairly distributed) supports at the level of the state or nation.

At the scale of planetary geoecologies, the focus shifts to the experience of all humans, and, occasionally, non/more-than-humans. Here, systematic unsustainability is positioned as a vulnerability faced by everyone and everything (albeit unevenly), with justice sought for all humans globally (and sometimes non/more-than-humans). Generally, more robust or more fairly distributed supports at a global level are offered as responses.

As Table 1 shows, there are many social justice issues to be addressed within education-migration, some of which are contradictory or incompatible. For the remainder of the paper, I use the Canadian education-migration crisis point of COVID-19 as an illustration. For context, I first provide a description of Canadian education-migration just before COVID-19 was detected in Canada in 2020.

\section{Education-migration in Pre-COVID-19 Canada}

By imploring international students to stay, Minister Mendicino offered an explicit public acknowledgement that Canadian international student policy had become "synonymous with immigration policy" (Trilokekar \& El Masri, 2019 , p. 47). For decades, IRCC viewed the two arenas separately, refusing the entry of would-be international students who expressed dual intent (i.e., a

\footnotetext{
${ }^{1}$ IRCC distinguishes between its Temporary Foreign Worker Program and International Mobility Program. In this paper I refer to workers in both categories as TFWs.
} 
desire to remain in Canada permanently after their studies). But over the past 20 years, Canada gradually developed its own dual intent, coming to view post-secondary international students as a source of not only temporary workers (IRCC, 2018), but also of highly desirable immigrants (Brunner, 2017; Tremblay, 2005; Trilokekar \& El Masri, 2019; Williams et al., 2015). ${ }^{2}$ By 2019, education-migration played a major role in both temporary and permanent migration flows.

Contemporary Canadian immigration has long been viewed by the government as an essential tool for population and economic growth. Despite a record-low fertility rate (StatsCan, 2020a), Canada's 2018/2019 population growth rate was the highest in roughly 30 years, driven primarily by relatively high levels of immigration (StatsCan, 2019) which placed Canada's net migration rate among the highest globally (UN DESA, 2019). Immigration was expected to account for $100 \%$ of workforce net growth in the near future (GAC, 2019).

In the eyes of the Organisation for Economic Co-operation and Development (OECD, 2019), Canada's economic immigration system was "widely seen as a role model for successful migration management" (p. 13) in its ability to solve a so-called problem faced by immigrant-dependent countries: how to select the most desirable immigrants who will efficiently integrate into their labour markets. Canada succeeded in two ways. First, the 2015 introduction of Express Entry promoted a more flexible, demand-driven approach, shifting from a backlogged first come, first served mandate to a nimbler, just-in-time selection process. By ranking applicants and then extending rolling invitations to those meeting an adjustable cut-off number, the government could, theoretically, fine-tune its selection criteria and respond to immediate labour market demands.

Second, Canada followed global immigration trends (Akbari \& MacDonald, 2014; Boucher \& Cerna, 2014) by relying on a two-step approach in which permanent residents (PRs) were selected not from abroad but from among TFWs already in Canada. Through the introduction of Provincial Nominee Programs (PNPs) in 1998 and the federal Canadian Experience Class (CEC) in 2008, Canada benefitted from more reliable evidence of labour market success based on actual participation in Canada (Hou et al., 2020; Sweetman \& Warman, 2010). This was a supposed antidote to the known "brain waste" or "overeducation" among those immigrants (selected from abroad) unable to leverage their human capital in Canada (Crossman et al., 2020; Hou et al., 2020; Lo et al., 2019).

These changes had a notable impact. The number of new two-step economic immigrants with Canadian work experience rose dramatically (from eight percent in 2000 to $46 \%$ in 2018) as did the number of TFWs in

\footnotetext{
${ }^{2}$ That said, some study permit applications are still refused for dual intent (e.g. Pisarevic v. Canada [Citizenship and Immigration], 2019), especially those from the Global South (Tao \& Arib, 2020).
} 
Canada (roughly 60,000 in 2000 to 429,300 in 2018) (Crossman et al., 2020). Instead of selecting immigrants and supporting their integration, Canada increasingly selected workers, affording the labour market more direct influence over who proceeded to the second step. Some TFWs such as seasonal agricultural workers were permanently temporary, while others, generally higher-skilled, were temporarily temporary - that is, on a PR pathway (Rajkumar et al., 2012). Regardless, a period of provisional admittance and conditional inclusion had become a prominent feature of Canadian immigration.

Concurrently, another temporary resident selection process with direct impact on the pool of TFWs expanded dramatically: the recruitment of international students (OECD, 2019). By 2019, Canada ranked among the highest in the world both in its proportion and total number of international students (IIE, 2019; UNESCO UIS, 2022). Canadian public postsecondary enrolment's modest $2018 / 19$ rise $(1.8 \%)$ was driven entirely by international students, whose enrolment increased while domestic enrolment fell; the proportion of international students rose from $6.4 \%$ to $16.2 \%$ in a decade (StatsCan, 2020b).

International students have been considered economically important since the 1980s (McCartney, 2020). Since then, the Canadian economy grew dependent on their tens of billions of dollars in annual expenditures, which, by 2019 , had a greater impact "than exports of auto parts, lumber or aircraft" (GAC, 2019, p. 2). In Canada, public HE is funded through a combination of low to medium public expenditures and relatively high tuition fees in comparison to other OECD countries, and it responded to budget shortfalls and enforced domestic tuition caps with hikes in largely unregulated international student fees (Pechar \& Andres, 2011; Williams et al., 2015). By 2019 , international undergraduate tuition was roughly five times the average domestic university tuition rate, with approximately $40 \%$ of all tuition fees in Canada paid by international students (StatsCan, 2020e).

International students are a heterogeneous category (King \& Raghuram, 2013; O'Connor, 2018), and not all are recruited for, or pay, tuition. In general, however, international student policies are uniquely located "at the confluence of migration policies and policies affecting the services industry, but where the services are sold to the migrant rather than provided by them" (Riaño et al., 2018, p. 291). Due in part to constant public reminders of their economic importance (e.g., IRCC, 2021a) and a neoliberal climate positioning $\mathrm{HE}$ as a commodity, they are often read as unproblematic, transient consumers (contributing to the economy) as opposed to TFWs (competing in the economy). Although international students are indeed framed by racialized tropes in which they are sometimes positioned as competitors (Stein \& Andreotti, 2016), they remain relatively acceptable to the public in comparison to other migrant categories (O'Connor, 2018).

In reality, their work authorization - whether during or after studies - has also been permitted, and used as a recruitment tool, since the 1980s (IRCC, 
2018). The typical international student transition entails three steps as part of a unique three-step immigration process (Brunner, in press): (1) as a study permit holder, which allows part-time work, (2) as a post-graduation work permit (PGWP) holder, and (3) if certain criteria are met (e.g., one year of skilled Canadian work experience), as a PR (see Figure 1).
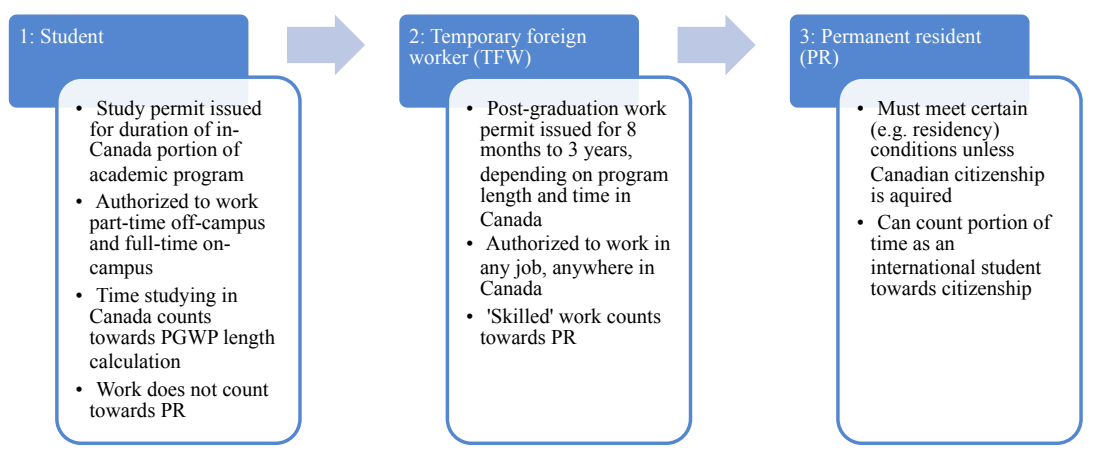

Figure 1. Canadian three-step education-migration process.

Designed to "(1) attract international students to Canada; (2) increase [their] participation in the Canadian labour market; and (3) provide [them] with a pathway to [PR]" (CIC, 2015, p. 5), the government considers the PGWP "generous" (CIC, 2015, p. 6; IRCC, 2018), as it is among the longest and least restricted of its type in the world (OECD, 2019). The PGWP is thus a selling point over competitor countries, leading Canada to be described as among the most welcoming so-called host countries for international students (e.g., Gopal, 2016; Lo et al., 2019). While not directly responsible, there is a correlation between the 2008 expansion of Canada's PGWP program and increasing international student numbers (CIC, 2015).

In combination, international students' economic importance, relatively benign political position, existing work pathways, and the fact that most are "young, have Canadian educational qualifications and in-demand labour skills, and are proficient in one of [Canada's] official languages" led them to be seen as "ideal" immigrant candidates (GAC, 2019, introduction), despite ongoing questions regarding their actual labour market outcomes (CIC, 2015; Hou \& Lu, 2017; IRCC, 2019). Largely self-funded, international students were also cost-effective immigrants for the government; their human capital was pre-vetted by academic application systems, and their subsequently limited integration needs (Trilokekar \& El Masri, 2019, p. 45; Hawthorne, 2012; OECD, 2019) were largely provided by education institutions. With immigration positioned (whether implicitly or explicitly) as a possibility, student and immigrant recruitment merged. 
However, Canada struggled to meet international student retention goals. Among those who arrived in the 1990s and early 2000s, roughly a quarter transitioned within 10 years ( $\mathrm{Lu} \& \mathrm{Hou}, 2015)$, and more recent numbers have been lower than anticipated (Tao \& Arib, 2020). Not all international students aspire to immigrate, but informal polling shows widespread intentions to immigrate (Canadian Bureau for International Education, 2018; Esses et al., 2018), leaving significant capacity for systemic growth from a government perspective. It is here, having described a system viewed as integral to the future of Canada, that I shift to COVID-19.

\section{Key Education-migration Related COVID-19 Policy Responses}

On March 12, 2020, IRCC tabled its 2020-2022 Immigration Levels Plan; four days later, Canada's unprecedented COVID-19 related travel restrictions reduced foreign entry to Canada to a trickle as education institutions scrambled to transition to virtual learning. These changes led to three key impacts on Canadian education-migration: (1) a (partially) lost cohort of international students physically present in Canada, (2) the subsequent loosening of PGWP eligibility requirements, and (3) indications of a heavier future reliance on international students as immigrants.

Lost Cohort: Once instruction was fully virtual, many enrolled international students left Canada. IRCC quickly included study permit holders on their list of foreign nationals permitted to enter Canada - if their travel was essential. Determining the essential threshold was left to individual officers upon students' arrival; for example, if courses were entirely online, travel generally did not qualify. Many remained abroad.

The travel restrictions had a bigger impact on incoming students. The Forum of Ministers Responsible for Immigration "reaffirmed the importance of newcomers, particularly international students, in keeping the economy and Canada's communities moving forward" in July 2020 (IRCC, 2020b, para. 4). Yet it was not until October 2020, after the start of the academic term, that IRCC amended its travel restrictions to allow new incoming international students to enter Canada. Even then, service interruptions and application difficulties continued to present obstacles (Cyr \& Landry, 2020; Hiebert, 2020). Combined with a reluctance to pay high tuition fees for online education, some students deferred. Roughly half of those expected arrived by the fall of 2020 (Hiebert, 2020).

Loosened PGWP Eligibility: The PGWP is a high-stakes document for students wishing to immigrate; it can be held only once in a lifetime and is often the culmination of significant financial and educational investment. To be eligible, students must continuously maintain full-time student status in Canada, of which distance learning may compose up to $50 \%$. The permit 
length is determined by the length of the program. In essence, the factors in determining PGWP eligibility are the length of time spent physically in Canada while maintaining continuous, full-time, and in-person studies.

COVID-19 disrupted all this: many students were physically outside Canada, studying virtually, unable to maintain a full-time course load, and/or facing study interruptions. Normally, this would render many ineligible for the PGWP, impacting not only international students' long-term plans but also institutional recruitment and national immigration targets. In response, Canada tweaked its PGWP policies multiple times: (1) students already in Canada remained eligible for the PGWP even if they failed to meet the continuous, full-time, or in-person requirements due to COVID-19, and (2) students outside Canada remained eligible even if they failed to meet the inperson or physical presence in Canada requirements (Cyr \& Landry, 2020). Later, in January 2021, IRCC recognized that high unemployment prevented many PGWP-holders from meeting PR eligibility and announced that PGWPholders could apply for an additional 18-month open work permit.

Increased Focus on International Students as PRs: Overall, Canada saw a dramatic decline in not just international students but all non-citizen/PR 2020 entries (StatsCan, 2020d), and the travel restrictions' impact on Canada's population growth was "profound" (StatsCan, 2020c). The federal government subsequently announced relatively high immigration targets for the next three years to make up for 2020's shortfall (IRCC, 2020a). Yet with travel restrictions still in place and applicants outside of Canada facing processing delays, two-step immigration became the primary source of PRs (StatsCan, 2020d). IRCC's PGWP quasi-extension indicated its hopes of retaining as many international students as possible. Similarly, a historic Express Entry draw in February 2021 inviting 27,332 Canadian Experience Class (CEC) applicants to apply (close to six times the previous largest draw) at a Comprehensive Ranking System cut-off score of just 75 (less than half the previous record cut-off score) (IRCC, 2021) indicated the government's willingness to accept virtually any applicant meeting the minimum CEC requirements. Many were former international students. Finally, in May 2021, the government opened 40,000 PR spots specifically for recent English-speaking graduates from Canadian institutions; the quota was filled just a day later (IRCC, 2021c).

Globally, Canada's COVID-19 response was considered relatively supportive for international students (e.g., Bilecen, 2020), and industry analysists predicted Canada would be "the big winner" in future international student enrolments (Ross, 2020, para. 13). Yet these policy decisions also point to important questions of "who and what can move (or stay put), when, where, how, under what conditions, and with what meanings" - that is, questions of mobility justice (Sheller, 2018, p. 11). In what follows, I return to the four previously mentioned scales (individuals, education institutions, state 
immigration regimes, and planetary geoecologies) to highlight four new issues that arose due to COVID-19. Once again, I stress that these scales are non-exhaustive, and this paper only gestures towards the full complexities; I outline them here as an articulation of what future research may more deeply explore.

\section{Individuals: Those who are Absent or Unseeable}

There is no doubt that individual international students and recent graduates were heavily impacted by COVID-19. Initial global research and media accounts pointed to the exacerbation of existing vulnerabilities, including deteriorated mental health, threats of (or actualized) status loss, fears of academic interruption, lack of adequate accommodation and food, job loss and financial concerns, loneliness, and concerns about family wellbeing (Bilecen, 2020; Coulton, 2020; Firang, 2020), while Chinese and other Asian students experienced particular social exclusion and racism (Newbold, 2020; Zhai \& Du, 2020).

Canada's policies largely underscored the country's paradoxical reliance on, yet conditional inclusion of, temporary residents in Canada. Allowing international students deemed essential to temporarily work more than 20 hours per week (IRCC, 2020c, para. 1) signaled not only their importance to the labour market but also the expectation that they not rely on public support. There is some evidence that employed study permit holders were concentrated in the service sector; while this disproportionally exposed them to COVID-19, international students were also more likely than temporary foreign workers and permanent residents to lose a job due to COVID-19 (WES, 2020). Although technically eligible for the Emergency Response Benefit, its minimum earnings requirement rendered it elusive for many international students, and they were ineligible for the Canada Emergency Student Benefit and Canada Student Service Grant. PGWP holders faced additional COVID-induced challenges as TFWs, such as job loss and worker exploitation (Crossman et al., 2020).

A mobility justice approach, however, also reminds us of those who are absent from, or unseeable in, the education-migration literature. Mobility capital (Kaufmann et al, 2004) is an unevenly distributed resource. If we consider international students as kinetically elite in that they disproportionally benefit from education-migration - even as they experience injustice - then mobility justice also asks us to consider the kinetic underclass or motility poor. Attending to this scale means noting the absence of wouldbe international students who were immobile due to increased study permit refusals (Tao \& Arib, 2020) or decimated family savings; future would-be international students who face the likelihood of increased class stratification within $\mathrm{HE}$ as a response to expected periods of austerity (Bilecen, 2020); and other potential migrants who are rendered less desirable through the 
reinforcement of international students' desirability (Trilokekar \& El Masri, 2017). We may also consider precarious low-wage Canadian workers whose skill development is neglected in favour of a reliance on TFWs (Crossman et al., 2020). This reliance may implicate PGWP-holders, whose median employment earnings are less than half those among recent Canadian graduates; they have been identified by the government as a "large low-wage workforce," (CIC, 2015, p. 9) unprepared for "long-term success" (IRCC, 2019 , p. 5). Finally, we might reflect on the implications of Canada's ongoing settler-colonialism for individual Indigenous people.

\section{Education Institutions: Tightening of HE and Immigration}

COVID-19's impacts on Canadian HE were highly uneven. The for-profit short-term language program sector took an immediate hit due to halted enrolment. While public universities and colleges, who receive just under a third of their revenue from tuition fees (StatsCan, 2020e), were able to retain some international enrolment, economic impacts varied based on institution type and region. Overall, Canadian HE's vulnerability in terms of its reliance on international student inflows had never been clearer (El Masri \& Sabzalieva, 2020; Esses et al., 2021).

From a mobility perspective, this points to an even further tightening of HE and immigration in three key ways. First, the importance of the PGWP as a recruitment tool became undeniable (e.g., Keung, 2020). Both HE and politicians lobbied the government to ensure virtual learning would not impact PGWP eligibility; one Member of Parliament said PGWP flexibility would "continue to make northern institutions a viable option for international students," implying that without the PGWP, international students would not consider such institutions (The Daily Press, 2020). When one such institution declared insolvency in 2021 after a string of complex financial and governing challenges, a prominent HE consultant blamed the university for not recruiting more international students (Buse, 2021).

Second, institutions positioned themselves as critical to immigration. HE formally requested from Parliament looser travel restrictions on international students and increased financial support to make up for their losses. Of significance was their justification for these requests: Universities Canada (2020) highlighted the role of international graduates in "revitalizing regions... struggling with outmigration and population decline" (p. 4), Colleges and Institutes Canada (2020) highlighted their importance in "meet[ing] immigration targets" (p. 3), and Languages Canada (n.d.) noted its role as "an essential part of the equation for meeting Canada's labour force and immigration goals" (para. 2). In this way, HE's role as a source of immigrants became justification for its funding.

Third, as admission letters paved an even clearer path towards PR, COVID-19 intensified the role of institutions as immigrant selection actors. 
We know the impacts of an employer-driven two-step Canadian immigration process: it becomes driven by corporate interests (Chatterjee, 2019), and top source countries skew Anglophone (Hiebert, 2019), reflecting not only employer concerns around language, but more significantly, racism and discrimination against foreign experience (e.g., Bhuyan et al., 2017; Lo et al., 2019; Oreopoulos, 2011). This is not to say that immigration systems preceding the current two-step model were not also racist. However, as public education institutions emerge as more significant immigrant selection actors, their short-term interests will increasingly shape the long-term make-up of Canada. HE itself is undergoing marketization and fiscal pressure due to the pandemic's economic recession. We have yet to fully see the impacts of a three-step immigration process driven increasingly by a neoliberal education system.

This tightening of $\mathrm{HE}$ and immigration raises larger questions around jurisdictional power. In Canada, responsibility for HE falls on the provinces, while immigration is controlled by a shared federal-provincial jurisdiction. However, the federal government is becoming more involved in HE by way of international education (e.g., its 2014 and 2019 national strategies), and provinces and territories are intensifying their regional immigrant recruitment activities (e.g., the relatively recent growth of Provincial Nominee Programs, many targeting international graduates). In the meantime, Canada's HE's funding model shifts more acutely from "publicly-financed" to "publiclyaided" (Usher, 2020). Although this paper lacks space to sufficiently discuss the changing landscape, a growing area of scholarship is recognizing its complexities (Tamtik et al., 2020).

\section{State Immigration Regime: Virtual Versus Physical Tensions}

The government has long walked a difficult line with the PGWP: as mentioned, it is both a potential source of competition for low-wage work and a powerful recruitment tool for HE. This has led to internal scrutiny of the PGWP and the international student program more generally to ensure international students are not using study permits "to gain full access to the Canadian labour market" (Regulations Amending the IRPR 2012, para. 12) and academic programs are not "visa mills" (para. 10). Both are discourses of control, attempting to ensure migrants use education-migration only as the government intends (Merrick, 2013). Notably, these pre-COVID-19 fears focused on virtual learning as an area of potential fraud (Tao \& Arib, 2020), something COVID-19 quickly changed.

While online education was increasing in Canadian HE before COVID-19 (Johnson, 2019), COVID-19 accelerated the sector's interest. Ontario invested \$50 million in virtual learning (Government of Ontario, 2020), while some called for its use towards more ethical "international partnership models that enable Canadian HE to be delivered away from the traditional campus 
base" to reduce the reliance "on recruiting international students to Canada" (E1 Masri \& Sabzalieva, 2020, p. 326).

However, study permits and their associated entitlements were predicated on students physically entering Canada for in-person study. COVID-19's sudden push towards online education bifurcated mobility. For those international students stuck outside Canada, some entitlements were barred; those scheduled as teaching or research assistants, for example, were unable to get Social Insurance Numbers (and thus Canadian work). Yet tuition (despite drastic currency fluctuations), learning (despite major time zone differences), and motility (thanks to conditional study permit approvals and promises that distance learning would count towards a PGWP) continued to flow, although Canadian educational credentials earned virtually during the pandemic do not appear to count towards points in Express Entry's Comprehensive Ranking System. Still, for the first time, international students could accumulate mobility capital before entering Canada - that is, without physical international mobility.

A lack of physical presence in Canada was a loss to some (e.g., Canadian communities who relied on international students as renters and consumers). Yet it was a gain to others (e.g., students who preferred to remain outside Canada yet still accumulate the capital afforded by international education and migration). Some students avoided social injustices associated with Canadian presence, such as racism or limited rights as a temporary resident. While border restrictions were surely felt as a mobility limitation for many, the allowances also meant a freedom to return or remain, speaking to supplementation of "the question of who can travel... by the question of who can stay at home" (Ahmed et al., 2003, p. 7).

IRCC will soon have data on COVID-19-era PGWP-holders. If the longterm integration data is favourable for Canadian immigration objectives, the PGWP may shift to accommodate certain virtual programs, opening up new marketing opportunities for institutions. If not, virtual HE programs, which are likely to increase regardless, may find the strength of Canadian education tested if they are not connected to PGWP eligibility, especially at non-elite institutions.

\section{Planetary Geoecologies: Denials of the Past, Present, and Future}

As governments responded to COVID-19, two dominant yet contradictory narratives were revealed: "we are all in it together' and 'close the borders"” (Sharma, 2020, p. S-19). Social distancing was enforced on a global scale through travel restrictions (Sharma, 2020), with states like Canada trying to mitigate risk and externalize harms to "sacrifice zones" outside their borders (Sheller, 2020a), even while global financial systems and virtual technologies enabled the northward flow of economic benefits. 
The idea that physical movement should stop in response to COVID-19 threats - only now, after state sovereignty has been established - is itself "a postcolonial fantasy of domination" (Sharma, 2020, p. S-26). At this scale, we see denials of the past, present and future on a global level. There is a failure to recognize, for example, that "there is no mobility without the history of colonialism" (Kaplan, 2015, pp. 124-125); in other words, the movement of people across the globe today is intimately (though not exclusively) shaped by the colonial past and present in both direct and indirect ways. Many education-migration patterns are fueled by colonial histories and disparities, such as the predominant (but shifting) Global South to Global North movements, or the fact that the lower an international student's home country GDP, the more likely they will transition to PR status (Lu \& Hou, 2015; Prokopenko \& Hou, 2018).

There is also a failure to recognize that Canadian education-migration is bound up in an ongoing settler-colonial system in which "dreaming, even in inclusive and multicultural tones, of developing an ideal settled state implicitly supports the elimination of Indigenous peoples from this place" (Chatterjee, 2019, p. 24). Viewing international students as ideal immigrants who benefit Canada over others may ultimately be environmentally, economically, and emotionally unsustainable (Tallbear, 2019). Similarly, dreaming that this is the last pandemic, or that the state or HE will survive indefinitely, or that climate change is a distant event, may be a denial of the future when seen from this scale. Canada's education-migration system is not only embedded in such denials but actively reproduces them to the extent that the ethics of its very continuation comes into question.

The planetary geoecologies scale is where the interlocking structural forces behind education-migration (e.g., neoliberal capitalism, colonialism, meritocracy, imperialism) are most visible. It highlights frequently overlooked impacts, such as the way mobility contributes to environmental privilege and the effects of the climate crisis through both literal and figurative borders (Park \& Pellow, 2019). But it is also at this scale where one most keenly - and perhaps painfully, overwhelmingly, or fearfully - feels the magnitude and pervasiveness of the system's ethical complexities. It dares us to face more difficult questions. Here, we do not ask how educationmigration fails students, or how HE's role has changed, or if a state's selection criteria deliver on its promises - but whether such a system can be just to begin with.

\section{Addressing the Desire to Return to "Normal"}

As this paper seeks to illustrate, a mobility justice lens can help tease out paradoxes of not just international student mobility in times of crisis, but even theories of justice. Partial views of the system's injustices (e.g., focusing on implications only for international students) may foreclose 
impacts on others bound up in the same system. In this way we might see that modernity's shine is possible only through the denial of its shadow (Mignolo, 2000); that is, the aspects of modernity "which we often cherish as sacred grounds for our interpretations of social justice, paradoxically create the conditions of injustice we are trying to address" (Andreotti, 2012, p. 19). Even when strategically necessary, it is important to recognize the inherent trade-offs of limited social justice analyses to avoid, if possible, reproducing different harms in the process (Stein, 2019b).

Here I have shown, in a limited way, how articulating justice at varying scales may complexify existing conversations. Mobility justice helps us begin to conceptualize the problems, but like all frames it is limited. Articulation is of course not a solution, and highlighting relationships between (differently) vulnerable groups can exacerbate divisions in its own way. Sheller (2018) outlines normative "principles of mobility justice" (pp. 173-174) seeking "more collective, non-individualistic and commons-based understandings of mobility" (Sheller, 2019, p. 29). From this perspective, we might try to reimagine international student mobility beyond individualistic social mobility; if we continue to deny our collective entanglement (Stein et al., 2020), we are always limited by costs and benefits based on separability. Yet within our current meritocratic systems bound by the state, moving beyond an individualistic lens is a challenging task.

One response is to ask what we learn from reframing our attention "towards the practices, regulations, infrastructures, moorings, systems, discourses or regimes that allow for differential movements and forms of mobile and immobile existences among all kinds of people" (Raithelhuber et al., 2018, p. 12; emphasis added), a process which, in the case of (im)migration, requires questioning the state as a distributor of entitlements. While Sheller's (2018) set of principles include "fairness and equity in determining the freedom of movement across borders" (p. 174), she stops short of questioning borders altogether. Moving forward, education-migration may benefit from engagements with the ethics of states and borders more generally (Carens, 2013; Shachar, 2009; Walia, 2013).

Another response is "resisting the temptation for certainty, totality, and instrumentalization in Western reasoning by keeping our claims contingent, contextual, tentative, and incomplete" (Ahenakew, 2016, p. 333) - that is, not deferring a solution, but rather humbly letting go of the fantasy that there can be an easy solution and interrogating the (colonial) desire for purity and innocence in many social justice claims. Looking at justice from a multiscalar vantage point reminds us that all solutions are partial and bring problems of their own. We in HE especially (Stein, 2019c) need to reckon with the depth of our own complicity in education-migration injustices. An attentive awareness and visibilization of such paradoxes may help us stay with the trouble (Haraway, 2016) while moving the conversation in different directions. 


\section{Acknowledgements}

Thanks to Bill Reimer, Sharon Stein, and Vanessa Andreotti for generative feedback on earlier versions of this paper; Margaret Walton-Roberts and two anonymous reviewers for insightful suggestions; David Butz for astute editing support; and the guest editors for bringing this special issue together.

\section{References}

Ahenakew, C. (2016). Grafting Indigenous ways of knowing onto non-indigenous ways of being: The (underestimated) challenges of a decolonial imagination. International Review of Qualitative Research, 9(3), 323-340.

Ahmed, S., Castañeda, C., Fortier, A., \& Sheller, M. (2003). Introduction. In S. Ahmed, C. Castañeda, A. Fortier \& M. Sheller (Eds.), Uprootings/regroundings: Questions of home and migration (pp. 1-19). Bloomsbury Academic.

Akbari, A. H., \& MacDonald, M. (2014). Immigration policy in Australia, Canada, New Zealand, and the United States: An overview of recent trends. International Migration Review, 48(3), 801-822.

Andreotti, V. (2012). Education, knowledge and the righting of wrongs. Other Education: The Journal of Educational Alternatives, 1(1), 19-31.

Apostolidis, P., \& McBride, K. (2020). A conversation about work, precarity and political possibilities during COVID-19. Theory \& Event, 23(5), S-76-S-86.

Baas, M. (2019). The education-migration industry: International students, migration policy and the question of skills. International Migration, 57(3), 222-234.

Baglay, S. (2017). Is Canada a model for compassionate migration policy? In S. W. Bender \& W. F. Arrocha (Eds.), Compassionate migration and regional policy in the Americas (pp. 193-216). Palgrave Macmillan.

Beech, S. E. (2018). Adapting to change in the higher education system: International student mobility as a migration industry. Journal of Ethnic and Migration Studies, 44(4), 610-625.

Bender, S. W., \& Arrocha, W. F. (2017). Introduction. In S. W. Bender \& W. F. Arrocha (Eds.), Compassionate migration and regional policy in the Americas (pp. 1-15). Palgrave Macmillan.

Benz, A. (2019). Mobility (in)justice, positionality and translocal development in Gojal, Pakistan. In N. Cook \& D. Butz (Eds.), Mobilities, mobility justice and social justice (pp. 201-214). Routledge.

Bhuyan, R., Jeyapal, D., Ku, J., Sakamoto, I., \& Chou, E. (2017). Branding 'Canadian Experience' in immigration policy: Nation building in a neoliberal era. Journal of International Migration \& Integration, 18(1), 47-62.

Bilecen, B. (2020). COVID-19 pandemic and higher education: International mobility and students' social protection. International Migration, 58(4), 263-266.

Boucher, A., \& Cerna, L. (2014). Current policy trends in skilled immigration policy. International Migration, 52(3), 21-25.

Brooks, R., \& Waters, J. (2011). Student mobilities, migration and the internationalization of higher education. Springer.

Brunner, L. R. (2017). Higher educational institutions as emerging immigrant selection actors: a history of British Columbia's retention of international graduates, 2001-2016. Policy Reviews in Higher Education, 1(1), 22-41.

Brunner, L. R. (in press). 'Edugration' as a wicked problem: Higher education and three-step immigration. Journal of Comparative and International Higher Education.

Buse, D. K. (2021, June 26). Unmaking a university: Laurentian's insolvency. The Sudbury Star. https://www.thesudburystar.com/opinion/columnists/unmaking-a-university-laurentiansinsolvency 
Canadian Bureau for International Education. (2018, August 21). 2018 international student survey national results. Webinar. https://cbie.ca/learning/webinars/the-students-voicenational-results-from-the-2018-cbie-international-student-survey/

Carens, J. (2013). The ethics of immigration. Oxford University Press.

Chatterjee, S. (2019). Immigration, anti-racism, and indigenous self-determination: Towards a comprehensive analysis of the contemporary settler colonial. Social Identities, 25(5), 644661.

CIC (Citizenship and Immigration Canada). (2015, June). The post-graduation work permit program: Options for program redesign. Advice to Minister [internal report]. Obtained through Access to Information Act request no. A-2015-32618.

Colleges \& Institutes Canada. (2020, August). Canada's colleges and institutes: Restart, recover, build back better. 2021 budget submission to the House of Commons Standing Committee on Finance. https://www.collegesinstitutes.ca/news-centre/news-release/cicanissues-recommendations-to-build-back-better/

Cook, N., \& Butz, D. (2019). Moving toward mobility justice. In N. Cook \& D. Butz (Eds.), Mobilities, mobility justice and social justice (pp. 3-21). Routledge.

Coulton, M. (2020, November 9). How the pandemic has disrupted the lives of international students in Canada. Maclean's. https://www.macleans.ca/education/how-the-pandemichas-disrupted-the-lives-of-international-students-in-canada/

CPAC (Cable Public Affairs Channel). (2020, October 30). Federal immigration minister discusses latest immigration targets - October 30, 2020 [Video file]. https://youtu.be/nnlhaCSZzk

Cresswell, T. (2006). On the move: Mobility in the modern western world. Routledge.

Cresswell, T. (2011). Mobilities I: Catching up. Progress in Human Geography, 35(4), 550-558.

Cresswell, T. (2012). Mobilities II: Still. Progress in Human Geography, 36(5), 645-653.

Crossman, E., Hou, F., \& Picot, G. (2020). Two-step immigration selection: A review of benefits and potential challenges. Statistics Canada Economic Insights. Catalogue no. 11-626-X 2020009 - No. 111. https://www150.statcan.gc.ca/n1/pub/11-626-x/11-626-x2020009eng.htm

Cyr, E., \& Landry, L. (2020, November 19). The international student program in the COVID-19 context [Conference presentation]. IRCC immigration update presented at the Canadian Bureau for International Education Conference.

Dobusch, L., \& Kreissl, K. (2020). Privilege and burden of im-/mobility governance: On the reinforcement of inequalities during a pandemic lockdown. Gender, Work \& Organization, 27(5), 709-716.

El Masri, A., \& Sabzalieva, E. (2020). Dealing with disruption, rethinking recovery: Policy responses to the COVID-19 pandemic in higher education. Policy Design and Practice, 3(3), 312-333.

Esses, V., Sutter, A., Ortiz, A., Lou, N., Cui, J., \& Deacon, L. (2018). Retaining international students in Canada post-graduation: Understanding the motivations and drivers of the decision to stay. Canadian Bureau for International Education. http://p2pcanada.ca/library/retaining-international-students-in-canada-post-graduationunderstanding-the-motivations-and-drivers-of-the-decision-to-stay/

Esses, V., McRae, J., Alboim, N., Brown, N., Friesen, C., Hamilton, L., Lacassagne, A., Macklin, A., \& Walton-Roberts, M. (2021). Supporting Canada's COVID-19 resilience and recovery through robust immigration policy and programs. Royal Society of Canada. https://rsc-src.ca/en/research-and-reports/covid-19-policy-briefing/supportingcanada $\%$ E2\%80\%99s-covid-19-resilience-and-recovery

Firang, D. (2020). The impact of COVID-19 pandemic on international students in Canada. International Social Work, 63(6), 820-824.

GAC (Global Affairs Canada). (2019). Building on success: International education strategy (2019-2024). https://www.international.gc.ca/education/strategy-2019-2024-strategie.aspx

Geddie, K. (2014). Policy mobilities in the race for talent: Competitive state strategies in international student mobility. Transactions of the Institute of British Geographers, 40(2), 235-248. 
Glick Schiller, N. (2015). Explanatory frameworks in transnational migration studies: The missing multi-scalar global perspective. Ethnic and Racial Studies, 38(13), 2275-2282,

Glick Schiller, N., \& Çaglar, A. (2011). Locality and globality: Building a comparative analytical framework in migration and urban studies. In N. Glick Schiller \& A. Çaglar (Eds.), Locating migration: Rescaling cities and migrants (pp. 60-81). Cornell University Press.

Gopal, A. (2016). Visa and immigration trends: A comparative examination of international student mobility in Canada, Australia, the United Kingdom, and the United States. Strategic Enrollment Management Quarterly, 4(3), 130-141.

Government of Ontario. (2020). Ontario invests in virtual learning strategy. https://news.ontario.ca/en/release/59600/ontario-invests-in-virtual-learning-strategy

Hagan, S., \& Bolongaro, K. (2020, November 4). Canada expands citizenship to foreigners in bid to stem exodus. Bloomberg. https://www.bloomberg.com/news/articles/2020-1104/canada-expands-citizenship-to-foreigners-in-bid-to-stem-exodus

Haraway, D. (2016). Staying with the trouble: Making kin in the Chthulucene. Duke University Press.

Hawthorne, L. (2012). Designer immigrants? International students and two-step migration. In D. K. Deardorff, H. de Wit, J. D. Heyl \& T. Adams (Eds.), The SAGE handbook of international higher education (pp. 417-437). SAGE.

Hiebert, D. (2019). The Canadian express entry system for selecting economic immigrants: Progresses and persistent challenges. Migration Policy Institute. https://www.migrationpolicy.org/research/canadian-express-entry-system-selectingeconomic-immigrants

Hiebert, D. (2020, October 16). Canadian migration during and after the pandemic: How are admission patterns changing and what can we expect in the near future? [Webinar]. UBC Migration Speaker Series, Vancouver, Canada. https://youtu.be/L4hVwt9bu-w

Hou, F., \& Lu, Y. (2017). International students, immigration and earnings growth: The effect of a preimmigration host-country university education. IZA Journal of Development and Migration, 7(5), 1-24.

Hou, F., Crossman, E., \& Picot, G. (2020). Two-step immigration selection: Why did immigrant labour market outcomes vary by admission programs? Statistics Canada Economic Insights. Catalogue no. 11-626-X - 2020015 - No. 117. https://www150.statcan.gc.ca/n1/pub/11-626-x/11-626-x2020015-eng.htm

IIE (Institute of International Education). (2019). A quick look at global mobility trends. Project Atlas 2019 release. https:/www.iie.org/en/Research-and-Insights/Project-Atlas/ExploreData/Infographics/2019-Project-Atlas-Infographics

IRCC (Immigration, Refugees \& Citizenship Canada). (2018, April 20). Profile of Canada's international student movement: From temporary to permanent residents. http://p2pcanada.ca/wp-content/blogs.dir/1/files/2018/04/01-Angie-Larocque.pdf

IRCC (Immigration, Refugees \& Citizenship Canada). (2019, January 22). Post-graduation work permit program: Recommendations. Presentation to executive committee [internal report]. Obtained through Access to Information Act request no. 2A-2020-45188.

IRCC (Immigration, Refugees \& Citizenship Canada). (2020a). Government of Canada announces plan to support economic recovery through immigration. https://www.canada.ca/en/immigration-refugees-citizenship/news/2020/10/government-ofcanada-announces-plan-to-support-economic-recovery-through-immigration.html

IRCC (Immigration, Refugees \& Citizenship Canada). (2020b). Ministers responsible for immigration meet to jointly plan for the future of immigration in Canada amid COVID-19. https://www.canada.ca/en/immigration-refugees-citizenship/news/2020/07/ministersresponsible-for-immigration-meet-to-jointly-plan-for-the-future-of-immigration-in-canadaamid-covid-19.html

IRCC (Immigration, Refugees \& Citizenship Canada). (2020c). Removing barriers for international students working in essential services to fight COVID-19. https://www.canada.ca/en/immigration-refugees-citizenship/news/2020/04/removingbarriers-for-international-students-working-in-essential-services-to-fight-covid-19.html

IRCC (Immigration, Refugees \& Citizenship Canada). (2021a). Government of Canada announces new policy to help former international students live in, work in and continue 
contributing to Canada. https://www.canada.ca/en/immigration-refugeescitizenship/news/2021/01/government-of-canada-announces-new-policy-to-help-formerinternational-students-live-in-work-in-and-continue-contributing-to-canada.html

IRCC (Immigration, Refugees \& Citizenship Canada). (2021b). Ministerial Instructions respecting invitations to apply for permanent residence under the Express Entry system \#176 - February 13, 2021. https://www.canada.ca/en/immigration-refugeescitizenship/corporate/mandate/policies-operational-instructions-agreements/ministerialinstructions/express-entry-rounds/invitations-176.html

IRCC (Immigration, Refugees \& Citizenship Canada). (2021c). Temporary public policy to facilitate the granting of permanent residence for foreign nationals in Canada, outside of Quebec, with a recent credential from a Canadian post-secondary institution. https://www.canada.ca/en/immigration-refugees-citizenship/corporate/mandate/policiesoperational-instructions-agreements/public-policies/trpr-international-graduates.html

Johnson, N. (2019). Tracking online and distance education in Canadian universities and colleges: National survey of online and digital learning 2019 national report. Canadian Digital Learning Research Association. http://www.cdlra-acrfl.ca/wpcontent/uploads/2020/07/2019_national_en.pdf

Kaplan, C. (2015). Afterward: Mobile desires. In L. Montegary \& M. A. White (Eds.), Mobile desires: The politics and erotics of mobility justice (pp. 122-127). Palgrave Macmillan.

Kaufmann, V., Bergman, M., \& Joye, D. (2004). Motility: Mobility as capital. International Journal of Urban and Regional Research, 28(4), 745-756.

Keung, N. (2020, May 15). International students studying online will still qualify for Canadian work permits. The Toronto Star.

https://www.thestar.com/news/gta/2020/05/15/international-students-studying-online-willstill-qualify-for-canadian-work-permits.html

Kim, A. H., \& Kwak, M. (2019). Introduction: Education migration, social mobility, and structuring institutions. In M. Kwak \& A. H. Kim (Eds.), Outward and upward mobilities: International students in Canada, their families, and structuring institutions (pp. 3-22). University of Toronto Press.

King, R. \& Raghuram, P. (2013). International student migration: Mapping the field and new research agendas. Population, Space and Place, 19(2), 127-137.

Lan, S. (2015). State regulation of undocumented African migrants in China: A multi-scalar analysis. Journal of Asian and African Studies, 50(3), 289-304.

Languages Canada. (n.d.). Study safe corridor: For federal and provincial governments. https://www.languagescanada.ca/en/study-safe-corridor-for-government

Ley, D., \& Hiebert, D. (2001). Immigration policy as population policy. The Canadian Geographer, 45(1), 120-125.

Lo, L., Li, W., \& Yu, W. (2019). Highly-skilled migration from China and India to Canada and the United States. International Migration, 57(3), 317-333.

Locatelli, R. (2019). Reframing education as a public and common good: Enhancing democratic governance. Palgrave Macmillan.

Lu, Y., \& Hou, F. (2015, December 10). International students who become permanent residents in Canada. Statistics Canada: Insights on Canadian Society. https://www150.statcan.gc.ca/n1/pub/75-006-x/2015001/article/14299-eng.htm

Mahler, S. J., Chaudhuri, M., \& Patil, V. (2015). Scaling intersectionality: Advancing feminist analysis of transnational families. Sex Roles, 73(3-4), 100-112.

Maldonado-Maldonado, A. (2014). Academic mobility as social mobility or the point of no return. In A. Maldonado-Maldonado \& R.M. Bassett (Eds.), The forefront of international higher education: A Festschrift in honor of Philip G. Altbach (pp. 127-137). Springer.

Marginson, S. (2016). The worldwide trend to high participation higher education: Dynamics of social stratification in inclusive systems. Higher Education, 72, 413-434.

Marston, S. A. (2000). The social construction of scale. Progress in Human Geography, 24(2), 219-242.

McCartney, D. M. (2020). From "friendly relations" to differential fees: A history of international student policy in Canada since World War II [Unpublished PhD dissertation]. University of British Columbia. 
Merrick, B. (2013). Whose initiative? International student policy in the UK. In S. Sovic \& M. Blythman (Eds.), International students negotiating higher education: Critical perspectives (pp. 28-38). Routledge.

Mignolo, W. (2000). Local histories/global designs: Coloniality, subaltern knowledges, and border thinking. Princeton University Press.

Newbold, B. (2020, Oct. 1). COVID-19 has hardened Canadian views on immigration. The Conversation. https://theconversation.com/covid-19-has-hardened-canadian-views-onimmigration-146512

O'Connor, S. (2018). Problematising strategic internationalisation: Tensions and conflicts between international student recruitment and integration policy in Ireland. Globalisation, Societies and Education, 16(3), 339-352.

OECD (Organisation for Economic Co-operation and Development). (2019, August 13). Recruiting immigrant workers: Canada 2019.

https://www.oecd.org/migration/mig/recruiting-immigrant-workers-canada-20194abab00d-en.htm

Oreopoulos, P. (2011). Why do skilled immigrants struggle in the labor market? A field experiment with thirteen thousand resumes. American Economic Journal: Economic Policy, 3(4), 148-171.

Park, L. S., \& Pellow, D. N. (2019). Forum 4: The environmental privilege of borders in the Anthropocene. Mobilities, 14(3), 395-400.

Pechar, H., \& Andres, L. (2011). Higher-education policies and welfare regimes: International comparative perspectives. Higher Education Policy, 24(1), 25-52.

Pisarevic v. Canada (Citizenship and Immigration), 2019 FC 188 (CanLII).

Prokopenko, E., \& Hou, F. (2018). How temporary were Canada's temporary foreign workers? Population and Development Review, 44(2), 257-280.

Purkayastha, B. (2010). Interrogating intersectionality: Contemporary globalisation and racialised gendering in the lives of highly educated South Asian Americans and their children. Journal of Intercultural Studies, 3(1), 29-47. https://doi.org/10.1080/07256860903477696

Raithelhuber, E., Sharma, N., \& Schröer, W. (2018). The intersection of social protection and mobilities: A move towards a 'practical utopia' research agenda. Mobilities, 13(5), 685701.

Rajkumar, D., Berkowitz, L., Vosko, L. F., Preston, V., \& Latham, R. (2012). At the temporarypermanent divide: How Canada produces temporariness and makes citizens through its security, work, and settlement policies. Citizenship Studies, 16(3-4), 483-510.

Regulations Amending the IRPR (Immigration and Refugee Protection Regulations). (2012). Canada Gazette Part 1, 146 (52). https://www.gazette.gc.ca/rp-pr/p1/2012/2012-1229/html/reg1-eng.html

Riaño, Y., Van Mol, C., \& Raghuram, P. (2018). New directions in studying policies of international student mobility and migration. Globalisation, Societies and Education, 16(3), 283-294.

Ross, J. (2020, June 24). Pandemic to redistribute international student flows: Report. Times Higher Education. https://www.timeshighereducation.com/news/pandemic-redistributeinternational-student-flows-report

Shachar, A. (2006). The race for talent: Highly skilled migrants and competitive immigration regimes. New York University Law Review, 81(April), 148-206.

Shachar A. (2009). The birthright lottery: Citizenship and global inequality. Harvard University Press.

Sharma, N. (2020). The global COVID-19 pandemic and the need to change who we think "we" are. Theory \& Event, 23(5), S-19-S-29.

Sheller, M. (2011). Sustainable mobility and mobility justice: Towards a twin transition. In M. Grieco \& J. Urry (Eds.), Mobilities: New perspectives on transport and society (pp. 289304). Routledge.

Sheller, M. (2018). Mobility justice: The politics of movement in an age of extremes. Verso.

Sheller, M. (2019). Theorizing mobility justice. In N. Cook \& D. Butz (Eds.), Mobilities, mobility justice and social justice (pp. 22-36). Routledge. 
Sheller, M. (2020a, September 25). Mobility justice, climate migration and the lessons of pandemic (im)mobilities [Webinar]. UBC Migration Speaker Series, Vancouver, Canada. https://youtu.be/PVX5jz41oAo

Sheller, M. (2020b). Reconstructing tourism in the Caribbean: Connecting pandemic recovery, climate resilience and sustainable tourism through mobility justice. Journal of Sustainable Tourism, 29(9), 1436-1449.

Sheller, M., \& Urry, J. (2006). The new mobilities paradigm. Environment and Planning A: Economy and Space, 38(2), 207-226.

StatsCan (Statistics Canada). (2019). Canada posts the largest annual population increase in numbers. https://www150.statcan.gc.ca/n1/daily-quotidien/190930/dq190930a-eng.htm

StatsCan (Statistics Canada). (2020a). Births, 2019. https://www150.statcan.gc.ca/n1/dailyquotidien/200929/dq200929e-eng.htm

StatsCan (Statistics Canada). (2020b). International students accounted for all of the growth in postsecondary enrolments in 2018/2019. https://www150.statcan.gc.ca/n1/dailyquotidien/201125/dq201125e-eng.htm

StatsCan (Statistics Canada). (2020c). Population growth essentially stops due to COVID-19. https://www150.statcan.gc.ca/n1/daily-quotidien/201217/dq201217b-eng.htm

StatsCan (Statistics Canada). (2020d). Study: Increasing selection of immigrants from among temporary foreign workers in Canada. https://www150.statcan.gc.ca/n1/dailyquotidien/200722/dq200722b-eng.htm

StatsCan (Statistics Canada). (2020e). Financial information of universities for the 2018/2019 school year and projected impact of COVID-19 for 2020/2021. https://www150.statcan.gc.ca/n1/daily-quotidien/201008/dq201008b-eng.htm

StatsCan (Statistics Canada). (2020f). Canada's population estimates: Age and sex, July 1, 2020. https://www150.statcan.gc.ca/n1/daily-quotidien/200929/dq200929b-eng.htm

Stein, S. (2019a). Beyond higher education as we know it: Gesturing towards decolonial horizons of possibility. Studies in Philosophy and Education, 38(3), 143-161.

Stein, S. (2019b). Critical internationalization studies at an impasse: Making space for complexity, uncertainty, and complicity in a time of global challenges. Studies in Higher Education, 46(9), 1-14.

Stein, S. (2019c). Navigating different theories of change for higher education in volatile times. Educational Studies, 55(6), 667-688.

Stein, S., \& Andreotti, V. (2016). Cash, competition, or charity: International students and the global imaginary. Higher Education, 72(2), 225-239.

Stein, S., Andreotti, V., Suša, R., Ahenakew, C., \& Čajková, T. (2020). From “education for sustainable development" to "education for the end of the world as we know it." Educational Philosophy and Theory, 54(3), 274-287.

Sweetman, A., \& Warman, C. (2010). A new source of immigration: The Canadian experience class. Policy Options, 31(7), 58-61.

Tallbear, K. (2019). Caretaking relations, not American dreaming. Kalfou, 6(1), 24-41.

Tamtik, M., Trilokekar, R. D., \& Jones, G. (Eds.). (2020). International education as public policy in Canada. McGill-Queen's University Press. https://doi.org/10.2307/j.ctv18sqz9q

Tao, W., \& Arib, E. (2020, December 10). Canadian international students and the global pandemic: Law/policy, COVID-19 updates and the role of civil society organisations. Arenous Foundation webinar. https://vancouverimmigrationblog.com/category/cislaw/

The Daily Press. (2020, September 8). Changes for international students help north. The Daily Press. https://www.timminspress.com/news/local-news/changes-for-international-studentshelps-north

Tremblay, K. (2005). Academic mobility and immigration. Journal of Studies in International Education, 9(3), 196-228.

Trilokekar, R. D. \& El Masri, A. (2017). The '[h]unt for new Canadians begins in the classroom': The construction and contradictions of Canadian policy discourse on international education. Globalisation, Societies and Education, 15(5), 666-678.

Trilokekar, R. D. \& El Masri, A. (2019). "International students are...golden": Canada's changing policy contexts, approaches, and national peculiarities in attracting international students as future immigrants. In M. Kwak \& A. H. Kim (Eds.), Outward and upward 
mobilities: International students in Canada, their families, and structuring institutions (pp. 25-55). University of Toronto Press.

Tungohan, E. (2020). Settlement, separation and forming new families: A multi-scalar intersectional analysis of Filipino family immigration in Saskatchewan, Canada. Women's Studies International Forum, 83(2), 102403. https://doi.org/10.1016/j.wsif.2020.102403

United Nations. (2006). Governments can create 'triple wins' for migrants, country of origin, destination countries, secretary-general tells general assembly high-level dialogue. https://www.un.org/press/en/2006/sgsm10634.doc.htm

United Nations Department of Economic and Social Affairs (UN DESA). (2019). World population prospects. Net migration rate (per 1,000 population). https://population.un.org/wpp/DataQuery/

UNESCO UIS (United Nations Educational, Scientific and Cultural Organization Institute for Statistics). (2022). Number and rates of international mobile students, 2019 [Database]. http://data.uis.unesco.org/

Universities Canada. (2020). Building back better: Investing in Canada's universities for a sustainable COVID-19 recovery. https://www.univcan.ca/media-room/publications/prebudget-2021-submission-investing-in-universities-for-a-sustainable-covid-19-recovery/

Urry, J. (2000). Sociology beyond societies: Mobilities for the twenty-first century. Routledge. Urry, J. (2007). Mobilities. Polity Press.

Usher, A. (2020). The state of postsecondary education in Canada, 2020. Higher Education Strategy Associates. https://higheredstrategy.com/wp-content/uploads/2020/09/HESASPEC-2020-revised.pdf

van Lieshout, M., Dewulf, A., Aarts, N., \& Termeer, C. (2011). Do scale frames matter? Scale frame mismatches in the decision making process of a "mega farm" in a small Dutch village. Ecology and Society, 16(1), 38.

Walia, H. (2013). Undoing border imperialism. AK Press.

Williamson, R. (2015). Towards a multi-scalar methodology: The challenges of studying social transformation and international migration. In S. Castles, D. Ozkul \& M. A. Cubas (Eds.), Social transformation and migration (pp. 17-32). Palgrave Macmillan.

Williams, K., Williams, G., Arbuckle, A., Walton-Roberts, M., \& Hennebry, J. (2015). International students in Ontario's postsecondary education system, 2000-2012: An evaluation of changing policies, populations and labour market entry processes. Higher Education Quality Council of Ontario.

WES (World Education Services). (2020, December). Impact of COVID-19 on the economic well-being of recent migrants to Canada: A report on survey results from permanent residents, temporary workers, and international students in Canada. https://knowledge.wes.org/canada-report-impact-of-COVID-19-on-the-economic-wellbeing-of-recent-migrants-to-canada.html

Xiang, B. (2013). Multi-scalar ethnography: An approach for critical engagement with migration and social change. Ethnography, 14(3), 282-299.

Yang, P. (2020). Toward a framework for (re)thinking the ethics and politics of international student mobility. Journal of Studies in International Education, 24(5), 518-534.

Zhai, Y., \& Du, X. (2020). Mental health care for international Chinese students affected by the COVID-19 outbreak. Lancet Psychiatry, 7(4), e22. https://doi.org/10.1016/S22150366(20)30089-4 